\title{
Neonatal cardiac hypertrophy: the role of hyperinsulinism-a review of literature
}

\author{
Nina D. Paauw ${ }^{1}$ (D) Raymond Stegeman ${ }^{2,4}$ - Monique A. M. J. de Vroede ${ }^{3} \cdot$ Jacqueline U. M. Termote $^{4}$. \\ Matthias W. Freund ${ }^{5}$. Johannes M. P. J. Breur ${ }^{2}$
}

Received: 9 August 2019 / Revised: 30 October 2019 / Accepted: 31 October 2019 / Published online: 16 December 2019

(C) The Author(s) 2019

\begin{abstract}
Hypertrophic cardiomyopathy (HCM) in neonates is a rare and heterogeneous disorder which is characterized by hypertrophy of heart with histological and functional disruption of the myocardial structure/composition. The prognosis of HCM depends on the underlying diagnosis. In this review, we emphasize the importance to consider hyperinsulinism in the differential diagnosis of $\mathrm{HCM}$, as hyperinsulinism is widely associated with cardiac hypertrophy $(\mathrm{CH})$ which cannot be distinguished from HCM on echocardiographic examination. We supply an overview of the incidence and treatment strategies of neonatal $\mathrm{CH}$ in a broad spectrum of hyperinsulinemic diseases. Reviewing the literature, we found that $\mathrm{CH}$ is reported in 13 to $44 \%$ of infants of diabetic mothers, in approximately $40 \%$ of infants with congenital hyperinsulinism, in $61 \%$ of infants with leprechaunism and in 48 to $61 \%$ of the patients with congenital generalized lipodystrophy. The correct diagnosis is of importance since there is a large variation in prognoses and there are various strategies to treat $\mathrm{CH}$ in hyperinsulinemic diseases.

Conclusion: The relationship between $\mathrm{CH}$ and hyperinsulism has implications for clinical practice as it might help to establish the correct diagnosis in neonates with cardiac hypertrophy which has both prognostic and therapeutic consequences. In addition, $\mathrm{CH}$ should be recognized as a potential comorbidity which might necessitate treatment in all neonates with known hyperinsulinism.
\end{abstract}

\section{What is Known:}

- Hyperinsulinism is currently not acknowledged as a cause of hypertrophic cardiomyopathy (HCM) in textbooks and recent Pediatric Cardiomyopathy Registry publications.

What is New:

- This article presents an overview of the literature of hyperinsulinism in neonates and infants showing that hyperinsulinism is associated with cardiac hypertrophy $(\mathrm{CH})$ in a broad range of hyperinsulinemic diseases.

- As CH cannot be distinguished from HCM on echocardiographic examination, we emphasize the importance to consider hyperinsulinism in the differential diagnosis of $\mathrm{HCM} / \mathrm{CH}$ as establishing the correct diagnosis has both prognostic and therapeutic consequences.

Keywords Hypertrophic cardiomyopathy $\cdot$ Cardiac hypertrophy $\cdot$ Hyperinsulinemia $\cdot$ Hyperinsulinemic state

Communicated by Peter de Winter

Johannes M. P. J. Breur

h.breur@umcutrecht.nl

Nina D. Paauw

n.d.paauw-2@umcutrecht.nl

Raymond Stegeman

r.stegeman@umcutrecht.nl

Jacqueline U. M. Termote

j.termote@umcutrecht.nl

Matthias W. Freund

freund.matthias@klinikum-oldenburg.de
1 Department of Obstetrics, Wilhelmina Children's Hospital Birth Center, University Medical Center Utrecht, Utrecht, The Netherlands

2 Department of Pediatric Cardiology, Wilhelmina Children's Hospital, University Medical Center Utrecht, PO Box 85090, 3508, AB Utrecht, The Netherlands

3 Department of Pediatric Endocrinology, Wilhelmina Children's Hospital, University Medical Center Utrecht, Utrecht, The Netherlands

4 Department of Neonatology, Wilhelmina Children's Hospital Birth Center, University Medical Center Utrecht, Utrecht, The Netherlands

5 Department of Pediatric Cardiology, Klinikum Oldenburg, University of Oldenburg, Oldenburg, Germany 


$\begin{array}{ll}\text { Abbreviations } \\ \text { AGPAT } & \text { Acylglycerolphosphate acyltransferase } \\ \text { BSCL } & \text { Bernadelli Seip complete lipodystrophy } \\ \text { BWS } & \text { Beckwith-Wiedemann Syndrome } \\ \text { CDG } & \text { Congenital disorders of glycosylation } \\ \text { CHI } & \text { Congenital hyperinsulinism } \\ \text { HCM } & \text { Hypertrophic cardiomyopathy } \\ \text { HRAS } & \text { Harvey rat sarcoma } \\ \text { IGF } & \text { Insulin like Growth Factor } \\ \text { INSR } & \text { Insulin receptor } \\ \text { Kir } & \text { Potassium channel inward-rectifying } \\ \text { PHHI } & \begin{array}{l}\text { Persistent hyperinsulinemic hypoglycemia } \\ \text { of infancy }\end{array} \\ \text { PTRF } & \text { Polymerase I and transcript release factor } \\ \text { pUPD11p } & \begin{array}{l}\text { Paternal uniparental isodisomy for } \\ \text { chromosome 11p (pUPD11p) }\end{array} \\ \text { Sur } & \text { Sulfonylurea receptor }\end{array}$

\section{Introduction}

Hypertrophic cardiomyopathy (HCM) is defined as a disease in which the heart muscle becomes abnormally thick in the absence of abnormal loading conditions (hypertension, valve disease) with histological disruption of the myocardial structure/composition and in the absence of systemic disease [1]. In adults, HCM has a prevalence of $0.2 \%$ and a genetic origin in most of the cases. In contrast, childhood HCM is rare with a reported mean incidence of 4.7 per million, with a highest incidence in children $<1$ year is found ( 30 per million) [2]. In children, HCM has a heterogeneous etiology and is more often reported secondary to conditions such as endocrine and metabolic disorders. An extensive table of etiologies of pediatric HCM is listed in the excellent review by Moak et al. [3]. Inborn errors of metabolism (storage disease and mitochondrial disorders), malformation syndromes, and neuromuscular disorders contribute to one third of the pediatric $\mathrm{HCM}$, each reported in around $10 \%$ of cases of pediatric CHM. Sacromeric protein mutations resulting in HCM are found in about $50 \%$ of the cases; however, in the other half, a specific cause cannot be identified (idiopathic HCM) [3-5].

Hyperinsulinism is not generally mentioned as a cause of HCM in textbooks [6] and recent Pediatric Cardiomyopathy Registry publications [7], while a relation between hyperinsulinism and hypertrophy of the heart is widely reported in relation to hyperinsulinism such as in neonates of diabetic mothers in $1980[8,9]$ in patients with congenital hyperinsulinism $(\mathrm{CHI})$ [10], as well as in patients with leprechaunism [11] and congenital lipodystrophy [12]. This absence of hyperinsulinism in the list of differential diagnosis of HCM is probably due to the fact that hyperinsulinism does not per se cause HCM but is associated with cardiac hypertrophy $(\mathrm{CH})$ without meeting the criteria of histological and functional disruption needed to diagnose HCM. Despite this, $\mathrm{CH}$ is often, incorrectly, termed $\mathrm{HCM}$ in current literature. This might be caused by the fact that the distinction between HCM and $\mathrm{CH}$ cannot be made completely using echocardiographic evaluation. Therefore, we think that in the case of thickening of the heart muscle on ultrasound which suggests the presence of $\mathrm{HCM}, \mathrm{CH}$ due to hyperinsulinemia should also be considered in the differential diagnosis, especially since the diagnosis might have consequences for the prognosis and treatment of the neonate.

In order to highlight the importance of the association of hyperinsulinemia and $\mathrm{CH}$, this article presents a review on the literature of hyperinsulinism in neonates and infants to determine the frequency of $\mathrm{CH}$ in this specific population. In addition, we will discuss by which mechanisms $\mathrm{CH}$ might develop during hyperinsulinemic states and in which ways the diagnosis of hyperinsulinemic $\mathrm{CH}$ affects further work-up and treatment. A literature search was performed in the PubMed electronic database using the search terms: neonate and infant, in combination with hyperinsulinism and hypertrophic cardiomyopathy or cardiac hypertrophy. Appropriate articles were selected by two reviewers (NP and RS). Snowballing was performed using references cited in publications retrieved during the database search. In this report, we will strictly use the term HCM for the genetic variants that cause sarcomeric hear disease and $\mathrm{CH}$ for all other kinds of hypertrophy of the heart muscle. The term $\mathrm{CH}$ indicates the presence of left ventricular or septal hypertrophy following the definition of echocardiographic measured diastolic septal thickness or diastolic left ventricular wall thickness $\geq 2$ standard deviations above the mean (Z-score $\geq 1.96$; corrected for age, sex, and body size) [13-15].

\section{Association between cardiac hypertrophy and hyperinsulinism}

Our search revealed that the association between $\mathrm{CH}$ and hyperinsulinism is mainly observed in the neonate, although the occurrence in older infants has also been described [16, 17]. The etiology of hyperinsulinism in the neonate and infant can be subdivided into three categories: maternal diabetes, congenital hyperinsulinism (transient and persistent), and insulin resistance syndromes. Additionally, hyperinsulinism is sometimes observed in syndromes in which the mechanism behind the development of hyperinsulinism remains to be resolved such as in Costello syndrome. Syndromes such as Noonan and Leopard in which $\mathrm{CH}$ is often reported will not be included since hyperinsulinism is not a typical feature.

\section{Maternal diabetes}

Hyperglycemia in maternal diabetes can lead to fetal hyperinsulinism which persists transiently in the neonatal period. Infants of diabetic mothers may present with a variety of 
metabolic problems and have an increased risk of congenital malformations. As for the heart, patent ductus arteriosus and $\mathrm{CH}$ are the most prevalent abnormalities [18-21]. The exact incidence of $\mathrm{CH}$ in children of diabetic mothers remains unclear since the $\mathrm{CH}$ is asymptomatic in most cases. A literature search revealed nine studies reporting the numbers of $\mathrm{CH}$ in neonates of diabetic mothers (Table 1). The incidence ranged from 13 to $44 \%$ in mixed groups of asymptomatic and symptomatic neonates $[9,24,26]$. The widespread incidence of $\mathrm{CH}$ probably results from the lack of uniformity in these studies in terms of patient selection (type 1 , type 2 , and gestational diabetes), the degree of maternal glucose control, and the moment and place of referral. None of the studies reported the incidence of $\mathrm{CH}$ in small for gestational age babies or in neonates of diabetic mothers with worse glucose control.

A few studies showed a correlation between the development of $\mathrm{CH}$ in children and the type of maternal diabetes. Ullmo et al. showed that fetuses of mothers with type 1 diabetes have the highest risk to develop $\mathrm{CH}$, followed by type 2 diabetes and only a low percentage in gestational diabetes [26]. In addition, children with $\mathrm{CH}$ had mothers with higher $\mathrm{HbAlc}$ levels compared to those of children without $\mathrm{CH}$. In line with this, El-Ganzoury et al. found that higher $\mathrm{HbAlc}$ values were associated with a hypertrophied interventricular septum [27]. Several studies showed a trend towards increased $\mathrm{CH}$ in neonates with high birth weight $[18,27]$.

The effects of strict glycemic control to prevent $\mathrm{CH}$ remains controversial. Presumably in some studies the incidence of complications diminished by a rigorous control of maternal glycemia [26]. Other studies show that fetal $\mathrm{CH}$ may occur even with good glycemic control [21, 24]. To prevent $\mathrm{CH}$, glucose control might even need to be more stringent than current recommendations. However, it cannot be ruled out that other unknown factors may be involved in the development of $\mathrm{CH}$.

$\mathrm{CH}$ in neonates of mothers with diabetes is reversible as the stimulus for the insulin production disappears and is in most situations no longer detected on ultrasound after 6 months postnatally [24]. However, studies on the long-term cardiovascular consequences of transient cardiac hypertrophy in infancy are lacking.

\section{Congenital hyperinsulinism}

Congenital hyperinsulinism (CHI), previously called "nesiodioblastosis," can both be transient and persistent. The latter is also known as persistent hyperinsulinemic hypoglycemia of infancy (PPHI). Transient hyperinsulinism is generally caused by stressful conditions, such as perinatal asphyxia or intra-uterine growth restriction [28]. The pathophysiologic mechanism is unknown, and the hyperinsulinism disappears spontaneously within days or weeks after birth. In two newborns with transient congenital hyperinsulinism, severe obstructive but reversible $\mathrm{CH}$ was reported [29] (Table 2a). In persistent congenital hyperinsulinism, there is a focal or diffuse overproduction of insulin by the pancreas secondary to various genetic disorders. The incidence is estimated at 1 in 50,000 live births [34]. Hypoglycemia is the main feature and is associated with a high risk of seizures and cerebral morbidity. In most cases, persistent congenital hyperinsulinism is due to genetic

Table 1 Incidences of cardiac hypertrophy in infants of diabetic mothers

\begin{tabular}{|c|c|c|c|c|c|}
\hline Study & Type of diabetes & Population characteristics & $\begin{array}{l}\text { Moment 1st } \\
\text { ultrasound }\end{array}$ & $\begin{array}{l}\text { Patients } \\
\text { (number) }\end{array}$ & $\mathrm{CH}(\%)$ \\
\hline Gutgesell (1980) [9] & DM1, DM2, GD & $\begin{array}{l}\text { Symptomatic, asymptomatic } \\
\text { neonates }\end{array}$ & $\leq 1$ st week postn & 47 & 32 \\
\hline Sheehan (1986) [21] & $\mathrm{N} / \mathrm{R}$ & Well-controlled diabetes & $\mathrm{N} / \mathrm{R}$ & 20 & 35 \\
\hline Deorari (1989) [22] & DM1,2 (16\%), GD (84\%) & High risk antenatal clinic & $\leq 5$ days postn & 31 & 26 \\
\hline Vural (1995) [23] & $\mathrm{N} / \mathrm{R}$ & NICU or neonatology ward & $\mathrm{N} / \mathrm{R}$ & 56 & 30 \\
\hline Oberhoffer (1997) [24] & DM1 (59\%), GD (41\%) & $\begin{array}{l}\text { Tightly controlled diabetic } \\
\text { pregnancies }\end{array}$ & $\leq 5$ days postn & 104 & 25 \\
\hline $\begin{array}{l}\text { Abu-Sulaiman (2004) } \\
\text { [18] }\end{array}$ & Insulin dependent DM & Tertiary care centrum & $\leq 48 \mathrm{~h}$ postn & 100 & 38 \\
\hline $\operatorname{Tan}(2005)[25]$ & $\begin{array}{l}\text { DM1,2 (20\%), GD (50\%), IGT } \\
\quad(30 \%)\end{array}$ & Antenatal clinic & $\leq 48 \mathrm{~h}$ postn & 50 & 13 \\
\hline Ullmo (2006) [26] & $\begin{array}{l}\text { DM1 (18\%), DM2 (20\%), GD } \\
\quad(62 \%)\end{array}$ & Perinatal care unit & Pren with post-FU & 92 & 13 \\
\hline \multirow[t]{2}{*}{$\begin{array}{l}\text { El-Ganzouriy (2012) } \\
\text { [27] }\end{array}$} & $\begin{array}{l}\text { DM1 (35\%), DM2 (17\%), GD } \\
\quad(48 \%)\end{array}$ & $\mathrm{NICU}$ & $\leq 48 \mathrm{~h}$ postn & 69 & 44 \\
\hline & & & & 569 & 28 \\
\hline
\end{tabular}

$D M 1$ diabetes mellitus type 1,DM 2 diabetes mellitus type 2, $F U$ follow-up, $G D$ gestational diabetes, $H C M$ hypertrophic cardiomyopathy, $I G T$ impaired glucose tolerance, $N / R$ not reported, NICU neonatal intensive care unit, postn postnatally, pren prenatally 
defects in the pathway that regulate insulin secretion as outlined in a recent review [35]. Mutations in the Kir6.2 (KCNJ11 gene, omim \#600937) and SUR1 (ABCC8 gene, omim \#600509) subunits lead to permanent closure of the channel and account for $40-45 \%$ of all cases of congenital hyperinsulinism [36]. Until recently, $\mathrm{CH}$ was only reported in a few neonates with congenital hyperinsulinism [10, 30, 31]. In 2013, Huang et al. reviewed the charts of 68 infants with $\mathrm{CHI}$. In 25 patients, an echocardiogram was performed of which $10(40 \%)$ had $\mathrm{CH}$ and all of them required pancreatectomy [33]. After pancreatectomy, all patients showed improvement or complete resolution of the cardiac hypertrophy and accompanying cardiac dysfunction (Table 2b). The reported pattern of hypertrophy in these infants was mainly septal. Although $\mathrm{CH}$ in $\mathrm{CHI}$ is generally rather mild, it was occasionally reported to progress very rapidly to fatal obstructive $\mathrm{CH}$.

\section{Other causes of persistent hyperinsulinemic hypoglycemia of infancy}

There are no reports of $\mathrm{CH}$ in other PHHI syndromes such as hyperinsulinism-hyperammonemia (HI/HA) syndrome (omim \#606762) and in hyperinsulinemic hypoglycemia due to an activating mutation in the glucokinase gene (omim \#602485). Both syndromes are less common compared to $\mathrm{K}$-ATP CHI. The lack of reports of $\mathrm{CH}$ in these syndromes might result from the lower prevalence of these diseases or their less aggressive course.

\section{Insulin resistance syndromes}

Insulin resistance in the neonatal period and early life is associated with a few rare (mono)genetic syndromes. The main characteristics of insulin resistance syndromes are hyperglycemia, despite hyperinsulinemia, acanthosis nigricans, and gonadal dysfunction. $\mathrm{CH}$ is reported in a few patients with insulin resistance syndromes. The incidence of $\mathrm{CH}$ in the various forms of insulin resistance syndromes will be further outlined below.

Leprechaunism (Donohue syndrome omim \#246200)

Leprechaunism is a rare disease with an incidence of less than 1 per million births. The disorder is autosomal recessively inherited and characterized by extreme insulin resistance due to mutations in the insulin receptor (INSR) gene [37]. Features of the disease are severe intra-uterine growth retardation, diminished fat and muscle tissue, characteristic facies, and precocious puberty [38]. Termote et al. reviewed the literature of leprechaunism between 1980 and 2014 and retrieved 81 cases of leprechaunism of which 39 patients underwent cardiac examination [39]. Sixtyone percent of these patients showed signs of $\mathrm{CH}$ (Table 3). Mortality is extremely high in patients with leprechaunism [42-44] and $85 \%$ of the patients with $\mathrm{CH}$ die from heart failure [39]. The reported pattern of hypertrophy is mainly septal causing obstruction of the aortic outflow tract. In addition, a few authors report left- or biventricular hypertrophy [11, 43].

\section{Congenital generalized lipodystrophy}

Congenital generalized lipodystrophy includes a group of genetic diseases characterized by disturbances of adipocytes causing low body fat, accumulation of lipid in muscle and liver, and insulin resistance resulting in hyperinsulinemia [45]. Less than 300 cases are reported to date and mutations in several loci are found of which the most relevant are AGPAT2 in congenital generalized lipodystrophy type 1 (omim \#608594), seipin in

Table 2 Cardiac hypertrophy in transient (A) and persistent (B) congenital hyperinsulinism (CHI)

\begin{tabular}{|c|c|c|c|c|c|c|}
\hline Study & Population characteristics & $\begin{array}{l}\text { Moment 1st } \\
\text { ultrasound }\end{array}$ & $\begin{array}{l}\text { Patients } \\
\text { (number) }\end{array}$ & $\begin{array}{l}\mathrm{CH} \\
(\%)\end{array}$ & Treatment & Outcome \\
\hline \multicolumn{7}{|l|}{ A transient $\mathrm{CHI}$} \\
\hline Mehta (2003) [29] & $\begin{array}{l}\text { Atypical severe transient HOCM in } \\
\text { CHI }\end{array}$ & $\mathrm{N} / \mathrm{R}$ & 2 & a & Octreotide & $\begin{array}{l}\text { Improvement } 6 \mathrm{~W} \\
\text { Complete resolution } 3 \mathrm{M}\end{array}$ \\
\hline \multicolumn{7}{|l|}{ B Persistent CHI } \\
\hline Harris (1992) [10] & Progressive $\mathrm{CH}$ in persistent $\mathrm{CHI}$ & $\mathrm{N} / \mathrm{R}$ & 1 & a & Pancreatectomy & Condition resolved \\
\hline $\begin{array}{l}\text { Massin (1999) } \\
{[30]}\end{array}$ & Progressive $\mathrm{CH}$ in focal $\mathrm{CHI}$ & $\mathrm{N} / \mathrm{R}$ & 1 & a & Pancreatectomy & Complete resolution \\
\hline $\begin{array}{l}\text { Natarajan (2007) } \\
{[31]}\end{array}$ & $\mathrm{CH}$ in $\mathrm{CHI} \mathrm{ABCC} 8$ mutation & D10 & 1 & a & $\begin{array}{l}\text { Diazoxide, } \\
\text { octreotride }\end{array}$ & $\begin{array}{l}\text { Regressed } \\
\text { spontaneously } 8 \mathrm{M}\end{array}$ \\
\hline Zerah (2013) [32] & Rapidly progressive $\mathrm{CH}$ in $\mathrm{CHI}$ & D12/13 & 2 & a & Diazoxide & Died \\
\hline $\begin{array}{l}\text { Huang (2013) } \\
{[33]}\end{array}$ & $\begin{array}{l}\mathrm{CH} \text { in } \mathrm{CHI} \text { ABCC } 8(n=7), \mathrm{KCNJ} 11 \\
\quad(n=1) \text { mutation }\end{array}$ & Early postn & 25 & 40 & Pancreatectomy & Improved/resolved \\
\hline
\end{tabular}

$C H I$ congenital hyperinsulinism, $D$ day, $H C M$ hypertrophic cardiomyopathy, HOCM hypertrophic obstructive cardiomyopathy, $N / R$ not reported, $M$ months, Postn postnatally, $W$ weeks

${ }^{\text {a }}$ Not reported, since all patients with CHI (100\%) in these case reports showed HCM 
Table 3 Cardiac hypertrophy in insulin resistance syndromes

\begin{tabular}{|c|c|c|c|c|c|c|c|}
\hline Study & $\begin{array}{l}\text { Insulin resistance } \\
\text { syndrome }\end{array}$ & $\begin{array}{l}\text { Population } \\
\text { characteristics }\end{array}$ & $\begin{array}{l}\text { Moment 1st } \\
\text { ultrasound }\end{array}$ & $\begin{array}{l}\text { Patients } \\
\text { (number) }\end{array}$ & $\begin{array}{l}\mathrm{CH} \\
(\%)\end{array}$ & Treatment & Outcome \\
\hline $\begin{array}{l}\text { Termote (2016) } \\
\text { [39] }\end{array}$ & $\begin{array}{l}\text { Leprechaunism } \\
\text { (Donohue syndrome)* }\end{array}$ & HOCM & $21 \mathrm{D}$ & $\begin{array}{l}1 \\
39 \ddagger\end{array}$ & $\begin{array}{l}\dagger \\
61 \dagger\end{array}$ & Metformin & Died $2.5 \mathrm{M}$ \\
\hline $\begin{array}{l}\text { Friguls (2009) } \\
\text { [17] }\end{array}$ & BSCL $\S$ & HOCM & $4 \mathrm{M}$ & 1 & $\dagger$ & Dietary & $\begin{array}{l}\text { Normalized } \\
2 \mathrm{Y}\end{array}$ \\
\hline $\begin{array}{l}\text { Lupsa (2010) } \\
\quad[40]\end{array}$ & $\begin{array}{l}\text { Congenital generalized } \\
\text { lipodystrophy }\end{array}$ & $\begin{array}{l}\text { AGPAT2 } \\
\text { Seipin } \\
\text { LMNA } \\
\text { Unknown }\end{array}$ & & $\begin{array}{l}31 \\
-19 \\
-10 \\
-1 \\
-1\end{array}$ & $\begin{array}{l}61 \\
-53 \\
-80 \\
-100 \\
-0\end{array}$ & & $\begin{array}{c}\text { Severe CHF } \\
(n=2) \\
\text { Died }(n=4) \\
\text { by CHF }\end{array}$ \\
\hline $\begin{array}{l}\text { Jeninga (2012) } \\
\text { [41] }\end{array}$ & BSCL†† & HOCM & $4 \mathrm{M}$ & 1 & $\dagger$ & $\begin{array}{l}\text { Dietary, insulin, } \\
\text { metformin }\end{array}$ & $\begin{array}{l}\text { Normalized } \\
16 \mathrm{M}\end{array}$ \\
\hline
\end{tabular}

HOCM Hypertrophic obstructive cardiomyopathy, BSCL Berardinelli-Seip congenital lipodystrophy, CHF chronic hard failure

congenital generalized lipodystrophy type 2 (BSCL2) (omim \#269700), caveolin 1 in congenital generalized lipodystrophy type 3 (omim \#612526), and PTRF in congenital generalized lipodystrophy type 4 (omim \#613327) [46]. The proteins encoded by these genes have a key role in the lipid synthesis and droplet formation in the adipose tissue. Caveolin and PTRF are involved in caveolae formation, which are plasma membrane invaginations in which free fatty acids are taken up and conversed to triacylglycerols. AGPAT2 is the key enzyme in the synthesis of triacylglycerols and glycerophospholipids. The role of seipin is less clear, but it may be involved in the formation of lipid droplets [47]. $\mathrm{CH}$ is a feature that is observed in 48 to $61 \%$ of the patients with congenital generalized lipodystrophy [40] and has a higher prevalence in patients with seipin mutations (80\%) than with AGPAT2 (53\%), caveolin 1, and PTRF mutations [48] (Table 3). Although $\mathrm{CH}$ generally develops in the third decade, occasionally $\mathrm{CH}$ is observed before the age of 1 year $[16,17,47]$. The $\mathrm{CH}$ pattern in lipodystrophy patients is asymmetrical $[16,49,50]$.

\section{Other hyperinsulinemic syndromes with insulin resistance}

In patients with Rabson Mendenhal (omim \#262190) and Type A syndrome (omim \#610549), which are rare insulin resistance syndromes, $\mathrm{CH}$ is not reported in literature. This might be due to the fact that these patients in general have a more benign course and are diagnosed later in life [44].

\section{Beckwith-Wiedemann (omim \#130650)}

Beckwith-Wiedemann (BWS) is a congenital overgrowth syndrome with a reported incidence of 1:13.700 births. BWS is a complex multigenic disorder caused by dysregulation of imprinted growth regulatory genes within the chromosome $11 \mathrm{p} 15$ region including increased activity of the $I G F-2$ gene in many tissues [51]. Features of the disease are macroglossia, generalized visceromegaly, anterior abdominal wall defects, hemihypertrophy, an accelerated growth potential, and increased risk of tumor formation [52]. Hyperinsulinemic hypoglycemia is observed in 30-50\% of the patients [53-55]. In the majority of the BWS/11P overgrowth patients, the hypoglycemia is asymptomatic and resolves spontaneously. Only $5 \%$ of the BWS patients have hypoglycemia beyond the neonatal period. This persistent and severe hyperinsulinism phenotype is the result of a paternal uniparental isodisomy for chromosome 11p (pUPD11p) [56]. Most of these patients are refractory to diazoxide treatment and about half of them require a subtotal pancreatectomy.

Cardiac involvement in $\mathrm{BWS} / 11 \mathrm{P}$ overgrowth patients is mostly limited to mild spontaneously-resolving $\mathrm{CH}$ (Table 4). However, in patients with BWS and severe hyperinsulinism (by pUPD11p), it might be severe and obstructive [58]. The pattern of hypertrophy is mainly characterized by hypertrophy of the septal region $[58,64]$.

\section{Costello syndrome (omim \#218040)}

Costello syndrome is a rare congenital disease caused by mutations in the HRAS proto-oncogene [65]. Features of the disease are prenatally increased growth, postnatal growth retardation, coarse face, loose skin, developmental delay, and susceptibility for papillomata and malignancies [66]. Cardiac abnormalities are reported in $60-75 \%$ of the patients with Costello syndrome. These include a heterogeneous group of structural defects, cardiomyopathies, and tachyarrhytmias [59, 60]. $\mathrm{CH}$ is found in $20-34 \%$ of the Costello patients (Table 4). However, the relationship between $\mathrm{CH}$ and hyperinsulinism is unproved in this syndrome since increased insulin levels were not reported in most patients with $\mathrm{CH}$. In only four patients with $\mathrm{CH}$, hyperinsulinemic hypoglycemia was described [61, $62,67]$. Interestingly, the histology of the heart was reported 
Table 4 Cardiac hypertrophy in hyperinsulinism-associated syndromes

\begin{tabular}{|c|c|c|c|c|c|}
\hline Study & Hyperinsulinism-associated syndrome & Patients (number) & $\mathrm{CH}(\%)$ & Treatment & Outcome \\
\hline Greenwood (1977) [57] & BWS & 13 & 38 & $\mathrm{~N} / \mathrm{R}$ & $\mathrm{N} / \mathrm{R}$ \\
\hline Ryan (1989) [58] & BWS & 1 & a & Diazoxide & Resolution $7 \mathrm{M}$ \\
\hline Zerah (2013) $[115]^{\mathrm{b}}$ & BWS & 1 & a & Diazoxide & Died \\
\hline Siwik (1998) [59] & Costello & 30 & 20 & $\mathrm{~N} / \mathrm{R}$ & $\mathrm{N} / \mathrm{R}$ \\
\hline $\operatorname{Lin}(2002)[60]$ & Costello & 94 & 34 & $\mathrm{~N} / \mathrm{R}$ & $\mathrm{N} / \mathrm{R}$ \\
\hline Dickson (2004) [61] & Costello & 1 & a & $\mathrm{N} / \mathrm{R}$ & Died \\
\hline Sheffield (2015) [62] & Costello & 1 & a & None & Died \\
\hline Sun $(2005)[63]$ & $\mathrm{CDG}$ & 1 & a & None & Died \\
\hline
\end{tabular}

$B W S$ Beckwith-Wiedemann Syndrome, $C D G$ Congenital Disorders of Glycosylation, $N / R$ not reported

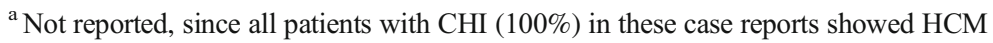

${ }^{\mathrm{b}}$ Data from abstract of Zerah et al. [32]

to be similar to the cardiac hypertrophy seen in infants of diabetic mothers [61].

\section{Congenital disorders of glycosylation}

Congenital disorders of glycosylation (CDG) are a genetically heterogeneous group of autosomal recessive disorders caused by defective biosynthesis or transfer of lipid-linked oligosaccharides or compromised processing of protein-bound oligosaccharides [68]. The clinical spectrum of the different CDG varies from multisystem to organ-restricted disease. Among the many CDG subtypes, CDG I (a,b,d) patients may suffer from hyperinsulinemic hypoglycemia [63, 69-71]. $\mathrm{CH}$ in these patients is rare, but it can be severe and obstructive [72]. The relationship of $\mathrm{CH}$ with hyperinsulinism is weak, since only one patient out of the reported cases of $\mathrm{CH}$ had hyperinsulinism (Table 4).

\section{Prenatal diagnosed $\mathrm{CH}$}

Occasionally $\mathrm{CH}$ is diagnosed prenatally [73]. One study reports that 7 out of 33 fetuses $(21 \%)$ with prenatally diagnosed $\mathrm{CH}$ were related to maternal diabetes [74]. In this study, no other hyperinsulinemic causes were mentioned and the remaining prenatally diagnosed $\mathrm{CH}$ cases were associated with Noonan's syndrome, alpha-thalassemia, twin-twin transfusion syndrome, and familial hypertrophy. Another study showed that the septal thickness in fetuses of diabetic mothers with $\mathrm{CH}$ is significantly associated with fetal insulin levels [75]. In addition, a follow-up study of the same group reports an association between regression of ventricular septum thickness and the decrease of insulin levels in the postpartum period in these prenatally diagnosed babies [76]. Prenatally diagnosed $\mathrm{CH}$ was not reported in one of the other mentioned hyperinsulinemic states.

\section{Morphologic, histologic, and hemodynamic characteristics of $\mathrm{CH}$ in hyperinsulinemic infants}

The pattern of $\mathrm{CH}$ related to hyperinsulinemic states is often described septal hypertrophy or left ventricular outflow tract obstruction [9, 77] (Fig. 1). On cardiac ultrasound, hearts of children with hyperinsulinemic disease are difficult to distinguish from other causes of $\mathrm{CH}$ as septal hypertrophy is the most common pattern described in HCM caused by sacromeric mutations. However, $\mathrm{CH}$ in the context of hyperinsulinism seems to differ microscopically and hemodynamically from other causes of $\mathrm{CH}$. While $\mathrm{CH}$ in context of hyperinsulinism is characterized by diffuse hyperplasia of cardiomyocytes with normal configuration, histologic examination of non-hyperinsulinemic $\mathrm{CH}$ is typically characterized by disarray of the muscle fibers [78], intramyocardial fibrosis [79], and interstitial collagen

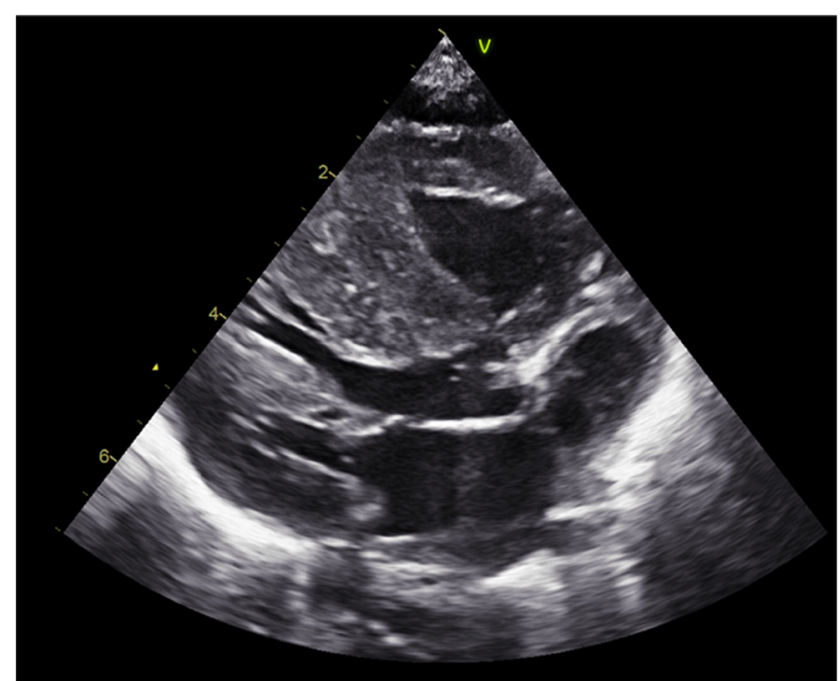

Fig. 1 Echocardiographic images taken from a patient with congenital hyperinsulinism. The ultrasound features of the heart of patient with insulin-associated cardiac hypertrophy show specific thickening of the intraventricular septum 
depositions [80]. These findings suggest that hyperinsulinemic hypertrophy is an exaggeration of normal cardiac growth due to overstimulation by growth factors affecting the heart as a whole rather than an intrinsic disease of the heart muscle. This might also explain the differences in pathophysiologic processes leading to cardiac symptoms and death. In non-hyperinsulinemic $\mathrm{CH}$ patients, myocyte disarray and fibrosis lead to electric instability causing dysarrhytmias and sudden death. However, in hyperinsulinemic patients, it is frequently observed that $\mathrm{CH}$ results in a stiff heart with high diastolic filling pressure resulting in reduced stroke volume and in the case of severe $\mathrm{CH}$ leads to the development of heart failure secondary to left ventricular outflow tract obstruction [58, 81]. In most of the hyperinsulinemic patients, the hypertrophy is asymptomatic and even reversible after normalization of insulin levels $[24,30,41,82]$.

\section{Insulin as a cardiac growth factor?}

The observed $\mathrm{CH}$ in hyperinsulinemic neonates and infants is presumably an exaggeration of the normal prenatal cardiac growth, in which biochemical signals and hormones including thyroid hormone, insulin, growth hormone, and IGF-I are involved [83]. The IGF/insulin system is composed by three ligands (IGF-I, IGF-II, and insulin), four receptors (insulin, IGF-I, IGF-II, and hybrid insulin/IGFI), and six IGF-binding proteins that regulate the bioactivity of the IGFs. Besides the insulin and IGF-I receptor, hybrid Ins/IGF receptors are described, that can function as IGF-I receptors and will not be further discussed. IGF-II, which is also highly homologous with IGF-I binds to the IGF-II receptor, which has as an intracellular IGF-II clearance function as well as to the insulin and IGF-I receptor and mainly has a role in prenatal development. Insulin and IGF-1 are polypeptides with a high degree of homology and interact with each other receptors [84]. Below, we discuss how both insulin and IGF1 signaling with their receptors might act as a cardiac growth factor. Although other factors might also play a role in the development of cardiac hypertrophy in the reviewed diseases, we discuss the arguments in favor for insulin as a cardiac growth factor in hyperinsulinemic infants with $\mathrm{CH}$.

Insulin In the presence of insulin, the insulin receptor (IR) phosphorylates insulin receptor substrate proteins (IRS proteins) that are linked to the activation of two main signaling pathways: the phosphatidylinositol 3-kinase (PI3K)-AKT/ protein kinase $\mathrm{B}(\mathrm{PKB})$ pathway, which is responsible for most of the metabolic actions of insulin, and the Ras-mitogen-activated protein kinase (MAPK) pathway and regulates expression of some genes to control cell growth and differentiation [85]. Insulin is merely known for its metabolic effects and the heart is an important target for insulin [86-88]. Insulin receptors are present in cardiomyocytes in a density comparable to other insulin sensitive tissues [87]. In humans, insulin responsiveness is established during the last trimester of gestation [89]. In late gestation, there is high fetal susceptibility as a result from higher insulin/ IGF-1 receptor expression on fetal cardiomyocytes and failure to downregulate insulin receptors in response to high insulin concentrations [90, 91]. Downstream of the insulin receptor, glycogen synthase kinase- $3 \beta$ negatively regulates cardiac hypertrophy. Since expression of this enzyme is inhibited by insulin, it is a potential mechanism for $\mathrm{CH}$ in the hyperinsulinemic fetus.

IGF-1 The heart is an important target for IGF-1 $[86,88]$ and IGF-I receptors are present in fetal and adult myocardium [88]. There is clinical and experimental evidence that IGF-I plays a key role in normal cardiac growth. In cultured neonatal rat cardiomyocytes, IGF-I induces cardiac hypertrophy and inhibits cardiomyocyt apoptosis. Mice treated with IV IGF-I and rats treated with SC IGF-I have increased protein levels, mainly localized in the heart [92]. IGF-1 is involved in pre- and postnatal growth [93]. IGF-I is secreted by various organs, mainly the liver, under the influence of growth hormone. Prenatal IGF-I-mediated growth is growth hormone independent, in contrast to postnatal growth [92]. Postnatally, childhood growth hormone deficiency is associated with reduced cardiac mass, which increases upon growth hormone treatment, whereas ventricular hypertrophy is noted in acromegaly.

While IGF-I is clearly a cardiac growth factor, its direct role in the development of $\mathrm{CH}$ is unproven. The association between IGFR levels and $\mathrm{CH}$ is difficult to establish since IGF plasma levels are not necessarily reflective of ligand available to bind to receptors in the heart. While insulin is made in the pancreatic $\beta$ cells and acts in an endocrine fashion, IGFs are made throughout the body, especially in the liver, skeletal muscle, and heart, and can act in endocrine and paracrine fashion. Since the concentration of IGF-BP1, one of the six IGF binding proteins to which IGF-I is bound, is influenced by insulin, any statement about the role of IGF-I in hyperinsulinism-induced $\mathrm{CH}$ is difficult.

Insulin and IGF1 receptors The role of the insulin receptor and the IGF-I receptor in cardiac growth has been investigated in transgenic mice. CIRKO mice with specific cardiac insulin receptor knock out have smaller hearts at birth [94]. Musclespecific IGF-I receptor knock-out mice appear normal, whereas double knock out mice (lacking the insulin and the IGF-I receptor) have a reduced heart size and early mortality, suggesting that the insulin receptor is more critical for cardiac growth than the IGF-I receptor [94]. 
Arguments in favor for insulin as a cardiac growth factor in hyperinsulinemic infants with $\mathrm{CH} \mathrm{CH}$ is observed in patients with a broad spectrum of hyperinsulinemic diseases indicating that the cardiac hypertrophy develops regardless of the etiology of the hyperinsulinism. Presumably, the association between hyperinsulinism and $\mathrm{CH}$ is underestimated as diagnostic options for $\mathrm{CH}$ by echocardiography have improved only in the last decades [95] and since many case reports have incomplete clinical and laboratory information including missing insulin levels. In addition, some patients with clinical evidence of hyperinsulinism do not have very elevated insulin levels. Clinical data emphasize that the severity of hyperinsulinism is the main factor to determine whether $\mathrm{CH}$ develops or not and whether $\mathrm{CH}$ is symptomatic or not since the clinical course of $\mathrm{CH}$ in general parallels the serum insulin levels. In congenital hyperinsulinism, patients that ultimately require pancreatectomy have the highest risk of $\mathrm{CH}$ [82]. In patients with milder congenital hyperinsulinism and infants of diabetic mothers, $\mathrm{CH}$ is mostly reversible and rarely fatal. In the latter patients, insulin levels are not always very elevated but inappropriately increased in the presence of hypoglycemia [96]. In some patients, insulin levels are often not increased at the time of hypoglycemia, because of the periodic release of insulin, which is missed by measuring a single serum sample [97]. This can be overcome by collecting several samples during hypoglycemia. In any case, in these patients, insulin levels may fail to predict the presence of $\mathrm{CH}$.

Another argument in favor of insulin as a cardiac growth factor is provided by the difference in mechanism, whereby hyperinsulinemia results in $\mathrm{CH}$ in unrelated diseases. Insulin is an anabolic hormone, and interaction with the cardiac insulin receptor as observed in congenital hyperinsulinism and in infants of diabetic mothers might explain the large weight and plethoric aspect of these patients. In contrast, neonates and infants with a defective insulin receptor appear emaciated. In infants of diabetic mothers and congenital hyperinsulinism, the CHCG is presumably due to the interaction of insulin with the intact insulin receptor. In insulin resistance syndromes, it is presumed that insulin acts through the IGF-1 receptor and not through the defective insulin receptor [98]. Indeed, several studies showed that insulin activates the IGF1 receptor at high concentrations of insulin, but not at low concentrations [84, 99, 100]. This was well documented in leprechaunism patients. Insulin binding to human leprechaunism fibroblasts is impaired, but mitogenic response is noted at high supraphysiologic concentrations of insulin and this response can be blocked by an antibody to the IGF-I receptor [100]. In leprechaunism, which is the most severe form of insulin resistance characterized by very high levels of insulin (up to $6000 \mu \mathrm{U} / \mathrm{ml}$ ), the $\mathrm{CH}$ is very severe and often the cause of death [39]. This is most pronounced in patients with a null mutation of the insulin receptor [101]. In patients with congenital lipodystrophy, it is not fully understood whether the cardiomyopathy is the direct effect of the mutant gene, an effect of lipotoxic substances or the result of hyperinsulinemia. A causal relationship between hyperinsulinemia and $\mathrm{CH}$ in patients with BSCL2 mutations is suggested in two patients in whom $\mathrm{CH}$ improved or even regressed after correction of the hyperinsulinism [16, 41].

\section{Implications for diagnostic work-up}

The presumed association between hyperinsulinism and $\mathrm{CH}$ emphasizes the need to consider hyperinsulinism in the differential diagnosis of HCM. The main differential diagnoses for cardiac hypertrophy due to hyperinsulinism are metabolic, mitochondrial, and storage disorders such as Pompe's disease, rather than primary idiopathic HCM, since they, like cardiomyopathy caused by hyperinsulinism, are not characterized by radial systolic hypercontractility which is virtually always present in idiopathic HCM [102]. In addition, the pattern of hypertrophy visualized by echocardiography might help in differentiating between the different etiologies as most patients with hyperinsulinemic disease are reported to have septal hypertrophy or left ventricular outflow tract obstruction, while the concentric hypertrophy pattern is a characteristic feature of metabolic and neuromuscular disorders [2]. However, recent studies using more advanced ultrasound devices should confirm the exact hypertrophy patterns in hyperinsulinemic diseases. It is suggested that in hyperinsulinemic states, the hypertrophy is not limited to the septum and also involves other parts of the heart which could not be imaged with previous echocardiographic techniques.

Regular glucose measurement to detect hypoglycemia is already part of the diagnostic work up of the pediatric $\mathrm{CH}$ patient and should alert the physician for underlying hyperinsulinemic disease. After establishing a diagnosis of hyperinsulinism, the etiology can be determined by a thorough physical examination for dysmorphic features, evaluation of pregnancy conditions, and appropriate laboratory investigations. The diagnosis can have significant impact on management and etiology-specific survival. Survival outcomes range from very poor as in leprechaunism to good with spontaneous regression of the hypertrophy in infants of diabetic mothers. Congenital hyperinsulinism and insulin resistance syndromes are genetic diseases, and diagnosis is important in terms of genetic counseling.

The other way around, $\mathrm{CH}$ should be recognized as a potential co-morbidity in all neonates with known hyperinsulinism. In terms of prevention, echocardiography should be performed not only in all patients with a clinical suspicion of $\mathrm{CH}$, but also in neonates and infants with known hyperinsulinism especially when requiring medication [103]. 


\section{Clinical interventions for $\mathrm{CH}$ in hyperinsulinemic infants}

Endocrine management Interventional options depend on the underlying cause of the hyperinsulinism. Diazoxide, glucagon, and the somatostatin analog octreotide can be effective in lowering insulin in patients with congenital hyperinsulinism based on K-ATP mutation. It should be noted that with diazoxide, there is a risk for cardiac dysfunction due to fluid overload [104]. Another concern with the use of diazoxide is the recent observation of pulmonary hypertension after diazoxide use [105], although this might be caused by (the undiagnosed underlying) cardiomyopathy. Sirolimus administration was successful in four infants with severe hyperinsulinemic hypoglycemia, who were unresponsive to diazoxide and octreotide [106]. Data on cardiac function were not available, but since sirolimus (formerly called rapamycin) inhibits the mTor pathway, which is part of two distinct growth promoting serine/threonine complexes in the Akt pathway of the receptor, it could potentially counteract $\mathrm{CH}$. In some cases, $\mathrm{CH}$ is resistant to medical therapy and pancreatic surgery is needed to reduce insulin production. Additional therapies for hyperinsulinism were reported on trial basis or in individual cases. In one patient with BSCL2, Metformin treatment, a mitochondrial glycerophosphate dehydrogenase [107], resulted in normalization of cardiac hypertrophy [41]. Recombinant IGF-1 was administered in several patients with leprechaunism $[108,109]$ and reported to stabilize severe obstructive cardiac hypertrophy in one patient [110]. Important to note is that IGF-1 treatment could potentially aggravate $\mathrm{CH}$, in view of the proposed pathway of $\mathrm{CH}$ development through the interaction with the IGF-1 receptors. Interestingly, reoccurrence of mild cardiac hypertrophy was observed during IGF-1 treatment in one patient with lipodystrophy [111]. Careful monitoring is therefore mandatory when IGF-1 is used in this setting. Finally, leptin and its analogue metreleptin improved metabolic parameters in patients with lipodystrophy and Rabson Mendenhall syndrome [87, 112].

Cardiac management In most instances of hyperinsulinemic $\mathrm{CH}$, no specific cardiac therapy is required apart from being very vigilant that the patient becomes neither hypoglycemic nor hypovolemic. Some patients with severe hyperinsulinemic $\mathrm{CH}$ might need supportive medication during diagnostic work-up. As outlined before, severe hyperinsulinemic $\mathrm{CH}$ is characterized by cardiac stiffness with decreased diastolic filling and an obstructive outflow tract, and patients might therefore benefit from B-blockers $[9,113,114]$. The choice of B-blocker should be carefully considered since some non-selective B-blockers (e.g., propranolol) are reported to have adverse effects in young infants leading to hypoglycemia [115].

\section{Conclusion}

In conclusion, we showed that hyperinsulinism is associated with $\mathrm{CH}$ in a broad range of hyperinsulinemic diseases and should therefore be considered in the differential diagnosis of HCM. Insulin might act as a cardiac growth factor in these diseases by interaction with cardiac insulin and IGF-1 receptors. However, the direct causal role of insulin in the development of $\mathrm{CH}$ in hyperinsulinemic disease still needs to be definitely established and other contributing factors need to be elucidated since $\mathrm{CH}$ is not present in all hyperinsulinemic states. However, the clear relationship between hyperinsulinemia and $\mathrm{CH}$ has implications for clinical practice as $\mathrm{CH}$ should be recognized as a potential co-morbidity in all neonates with known hyperinsulinism. Visa versa, hyperinsulinemic disease should be considered in neonates/young infants presenting with $\mathrm{CH}$. In the case of suspicion of hyperinsulinemic disease, establishment of the correct diagnosis is essential since it may have prognostic and therapeutic consequences.

Authors' contributions NDP and HB designed the search strategy, NDP and RS performed literature searches, NDP drafted the manuscript with help of MdV who added expertise on the endocrinology sections and JT who added expertise on leprechausnism, RS prepared the tables and figures, and HB and MWF edited and revised the manuscript. All authors reviewed and approved the final version of manuscript.

\section{Compliance with ethical standards}

Conflict of interest The authors declare that they have no conflict of interest.

Ethical approval This article does not contain any studies with human participants or animals performed by any of the authors.

Open Access This article is licensed under a Creative Commons Attribution 4.0 International License, which permits use, sharing, adaptation, distribution and reproduction in any medium or format, as long as you give appropriate credit to the original author(s) and the source, provide a link to the Creative Commons licence, and indicate if changes were made. The images or other third party material in this article are included in the article's Creative Commons licence, unless indicated otherwise in a credit line to the material. If material is not included in the article's Creative Commons licence and your intended use is not permitted by statutory regulation or exceeds the permitted use, you will need to obtain permission directly from the copyright holder. To view a copy of this licence, visit http://creativecommons.org/licenses/by/4.0/.

\section{References}

1. Elliott P, Andersson B, Arbustini E et al (2008) Classification of the cardiomyopathies: a position statement from the European Society Of Cardiology Working Group on Myocardial and Pericardial Diseases. Eur Heart J 29:270-276 https://doi.org/ehm342

2. Colan SD, Lipshultz SE, Lowe AM et al (2007) Epidemiology and cause-specific outcome of hypertrophic cardiomyopathy in children: findings from the Pediatric Cardiomyopathy Registry. 
Circulation 115:773-781. https://doi.org/10.1161/ CIRCULATIONAHA.106.621185

3. Moak JP, Kaski JP (2012) Hypertrophic cardiomyopathy in children. Heart 98:1044-1054. https://doi.org/10.1136/heartjnl-2011-300531

4. Kaski JP, Syrris P, Esteban MT et al (2009) Prevalence of sarcomere protein gene mutations in preadolescent children with hypertrophic cardiomyopathy. Circ Genet 2:436-441. https://doi.org/ 10.1161/CIRCGENETICS.108.821314

5. Nugent AW, Daubeney PE, Chondros P et al (2005) Clinical features and outcomes of childhood hypertrophic cardiomyopathy: results from a national population-based study. Circulation 112: 1332-1338 https://doi.org/CIRCULATIONAHA.104.530303

6. Kaski JP, Elliot P (2010) Chapter 49 Cardiomyopathies. In: Anderson RH, Baker EJ, Penny DJ (eds) Churchill Livingstone, Philadelphia USA, 3rd edn

7. Lipshultz SE, Orav EJ, Wilkinson JD et al (2013) Risk stratification at diagnosis for children with hypertrophic cardiomyopathy: an analysis of data from the Pediatric Cardiomyopathy Registry. Lancet 382: 1889-1897. https://doi.org/10.1016/S0140-6736(13)61685-2

8. Breitweser JA, Meyer RA, Sperling MA et al (1980) Cardiac septal hypertrophy in hyperinsulinemic infants. J Pediatr 96:535-539

9. Gutgesell HP, Speer ME, Rosenberg HS (1980) Characterization of the cardiomyopathy in infants of diabetic mothers. Circulation 61:441-450

10. Harris JP, Ricker AT, Gray RS et al (1992) Reversible hypertrophic cardiomyopathy associated with nesidioblastosis. J Pediatr 120:272-275

11. Rosenberg AM, Haworth JC, Degroot GW et al (1980) A case of leprechaunism with severe hyperinsulinemia. Am J Dis Child 134: 170-175

12. Rheuban KS, Blizzard RM, Parker MA et al (1986) Hypertrophic cardiomyopathy in total lipodystrophy. J Pediatr 109:301-302

13. of Cardiology Foundation/American Heart Association Task Force on Practice Guidelines AC, for Thoracic Surgery AA, of Echocardiography AS et al (2011) 2011 ACCF/AHA guideline for the diagnosis and treatment of hypertrophic cardiomyopathy: executive summary: a report of the American College of Cardiology Foundation/American Heart Association Task Force on Practice Guidelines. J Thorac Cardiovasc Surg 142:13031338. https://doi.org/10.1016/j.jtcvs.2011.10.019

14. Chubb H, Simpson JM (2012) The use of Z-scores in paediatric cardiology. Ann Pediatr Cardiol 5:179-184. https://doi.org/10. 4103/0974-2069.99622

15. Daubeney PE, Blackstone EH, Weintraub RG et al (1999) Relationship of the dimension of cardiac structures to body size: an echocardiographic study in normal infants and children. Cardiol Young 9:402-410

16. Bhayana S, Siu VM, Joubert GI et al (2002) Cardiomyopathy in congenital complete lipodystrophy. Clin Genet 61:283-287

17. Friguls B, Coroleu W, del Alcazar R et al (2009) Severe cardiac phenotype of Berardinelli-Seip congenital lipodystrophy in an infant with homozygous E189X BSCL2 mutation. Eur J Med Genet 52:14-16. https://doi.org/10.1016/j.ejmg.2008.10.006

18. Abu-Sulaiman RM, Subaih B (2004) Congenital heart disease in infants of diabetic mothers: echocardiographic study. Pediatr Cardiol 25:137-140. https://doi.org/10.1007/s00246-003-0538-8

19. Breitweser JA, Meyer RA, Sperling MA, Tsang RC, Kaplan S (1980) Cardiac septal infants hypertrophy in hyperinsulinemic. J Pediatr 96:535-539

20. Reller MD, Kaplan S (1988) Hypertrophic cardiomyopathy in infants of diabetic mothers: an update. Am J Perinatol 5:353358. https://doi.org/10.1055/s-2007-999722

21. Sheehan PQ, Rowland TW, Shah BL et al (1986) Maternal diabetic control and hypertrophic cardiomyopathy in infants of diabetic mothers. Clin Pediatr (Phila) 25:266-271
22. Deorari AK, Saxena A, Singh M, Shrivastava S (1989) Echocardiographic assessment of infants born to diabetic mothers. Arch Dis Child 64:721-724

23. Vural M, Leke L, Mahomedaly H et al (1995) Should an echocardiographic scan be done routinely for infants of diabetic mothers? Turk J Pediatr 37:351-356

24. Oberhoffer R, Hogel J, Stoz F et al (1997) Cardiac and extracardiac complications in infants of diabetic mothers and their relation to parameters of carbohydrate metabolism. Eur J Pediatr 156:262-265

25. Tan AE, Norizah WM, Rahman HA et al (2005) Umbilical artery resistance index in diabetic pregnancies: the associations with fetal outcome and neonatal septal hypertrophic cardiomyopathy. J Obstet Gynaecol Res 31:296-301 https://doi.org/JOG291

26. Ullmo S, Vial Y, Di Bernardo S et al (2007) Pathologic ventricular hypertrophy in the offspring of diabetic mothers: a retrospective study. Eur Heart J 28:1319-1325. https://doi.org/10.1093/ eurheartj/ehl416

27. El-Ganzoury MM, El-Masry SA, El-Farrash RA et al (2012) Infants of diabetic mothers: echocardiographic measurements and cord blood IGF-I and IGFBP-1. Pediatr Diabetes 13:189 196. https://doi.org/10.1111/j.1399-5448.2011.00811.x

28. Collins JE, Leonard J V (1984) Hyperinsulinism in asphyxiated and small-for-dates infants with hypoglycaemia. Lancet 2:311313. https://doi.org/S0140-6736(84)92685-0

29. Mehta A, Hussain K (2003) Transient hyperinsulinism associated with macrosomia, hypertrophic obstructive cardiomyopathy, hepatomegaly, and nephromegaly. Arch Dis Child 88:822-824

30. Massin MM, Van Elmbt G, Soyeur D (1999) Reversible hypertrophic cardiomyopathy in congenital hyperinsulinism. Acta Cardiol 54:359-361

31. Natarajan G, Aggarwal S, Merritt TA (2007) A novel mutation associated with congenital hyperinsulinism. Am J Perinatol 24: 401-404. https://doi.org/10.1055/s-2007-984408

32. Zerah MM, Anderson J, Davenport J, Thornton PS (2013) Fatal obstructive hypertrophic cardiomyopathy in two cases of neonatal congenital hyperinsulinism. The Endocrine Society's 95th Annual Meeting and Expo, San Francisco Presentation Number: SUN-610

33. Huang T, Kelly A, Becker SA et al (2013) Hypertrophic cardiomyopathy in neonates with congenital hyperinsulinism. Arch Dis childhoodFetal neonatal Ed. https://doi.org/10.1136/archdischild2012-302546

34. Stanley CA (1997) Hyperinsulinism in infants and children. Pediatr Clin North Am 44:363-374

35. Stanley CA (2016) Perspective on the Genetics and Diagnosis of Congenital Hyperinsulinism Disorders. J Clin Endocrinol Metab 101:815-826. https://doi.org/10.1210/jc.2015-3651

36. Flanagan SE, Kapoor RR, Hussain K (2011) Genetics of congenital hyperinsulinemic hypoglycemia. Semin Pediatr Surg 20:1317. https://doi.org/10.1053/j.sempedsurg.2010.10.004

37. Semple RK, Savage DB, Cochran EK et al (2011) Genetic syndromes of severe insulin resistance. Endocr Rev 32:498-514. https://doi.org/ 10.1210/er.2010-0020. https://doi.org/10.1210/er.2010-0020

38. Elsas LJ, Endo F, Strumlauf E et al (1985) Leprechaunism: an inherited defect in a high-affinity insulin receptor. Am J Hum Genet 37:73-88

39. Termote JU, Breur JM, de Vroede MA (2016) Hypertrophic cardiomyopathy in Donohue syndrome. Cardiol Young 26:815-818. https://doi.org/10.1017/S1047951115002437

40. Lupsa BC, Sachdev V, Lungu AO et al (2010) Cardiomyopathy in congenital and acquired generalized lipodystrophy: a clinical assessment. Medicine (Baltimore) 89:245-250. https://doi.org/10. 1097/MD.0b013e3181e9442f

41. Jeninga EH, de Vroede M, Hamers N et al (2012) A patient with congenital generalized lipodystrophy due to a novel mutation in BSCL2: indications for secondary mitochondrial dysfunction. JIMD Rep 4:47-54. https://doi.org/10.1007/8904_2011_86 
42. Zaccai TCF, Kalfon L, Klar A et al (2014) Two novel mutations identified in familial cases with Donohue syndrome. Mol Genet genomic Med 2:64-72. https://doi.org/10.1002/mgg3.43

43. Longo N, Langley SD, Still MJ, Elsas LJ (1995) Prenatal analysis of the insulin receptor gene in a family with leprechaunism. Prenat Diagn 15:1070-1074

44. Musso C, Cochran E, Moran SA et al (2004) Clinical course of genetic diseases of the insulin receptor (type A and RabsonMendenhall syndromes): a 30-year prospective. Medicine (Baltimore) 83:209-222 https://doi.org/00005792-200407000-00001

45. Garg A (2000) Lipodystrophies. Am J Med 108:143-152

46. Agarwal AK, Garg A (2006) Genetic basis of lipodystrophies and management of metabolic complications. Annu Rev Med 57:297311. https://doi.org/10.1146/annurev.med.57.022605.114424

47. Jeninga EH, Kalkhoven E (2010) Central players in inherited lipodystrophies. Trends Endocrinol Metab 21:581-588. https:// doi.org/10.1016/j.tem.2010.06.006

48. Agarwal AK, Simha V, Oral EA et al (2003) Phenotypic and genetic heterogeneity in congenital generalized lipodystrophy. J Clin Endocrinol Metab 88:4840-4847

49. Bjornstad PG, Semb BK, Trygstad O, Seip M (1985) Echocardiographic assessment of cardiac function and morphology in patients with generalised lipodystrophy. Eur J Pediatr 144:355-359

50. Klar A, Brand A, Hurvitz H et al (1993) Cardiomyopathy in lipodystrophy and the specificity spillover hypothesis. Isr J Med Sci 29:50-52

51. Li M, Squire JA, Weksberg R (1998) Molecular genetics of Wiedemann-Beckwith syndrome. Am J Med Genet 79:253-259

52. Engstrom W, Lindham S, Schofield P (1988) WiedemannBeckwith syndrome. Eur J Pediatr 147:450-457

53. Elliott M, Bayly R, Cole T et al (1994) Clinical features and natural history of Beckwith-Wiedemann syndrome: presentation of 74 new cases. Clin Genet 46:168-174

54. Munns CF, Batch JA (2001) Hyperinsulinism and BeckwithWiedemann syndrome. Arch Dis childhoodFetal neonatal Ed 84: F67-F69

55. DeBaun MR, King AA, White N (2000) Hypoglycemia in Beckwith-Wiedemann syndrome. Semin Perinatol 24:164-171

56. Kalish JM, Boodhansingh KE, Bhatti TR et al (2016) Congenital hyperinsulinism in children with paternal $11 \mathrm{p}$ uniparental isodisomy and Beckwith-Wiedemann syndrome. J Med Genet 53:53-61. https://doi.org/10.1136/jmedgenet-2015-103394

57. Greenwood RD, Somer A, Rosenthal A et al (1977) Cardiovascular abnormalities in the Beckwith-Wiedemann syndrome. Am J Dis Child 131:293-294

58. Ryan CA, Boyle MH, Burggraf GW (1989) Reversible obstructive hypertrophic cardiomyopathy in the Beckwith-Wiedemann syndrome. Pediatr Cardiol 10:225-228

59. Siwik ES, Zahka KG, Wiesner GL, Limwongse C (1998) Cardiac disease in Costello syndrome. Pediatrics 101:706-709

60. Lin AE, Grossfeld PD, Hamilton RM et al (2002) Further delineation of cardiac abnormalities in Costello syndrome. Am J Med Genet 111:115-129. https://doi.org/10.1002/ajmg.10558

61. Dickson PI, Briones NY, Baylen BG et al (2004) Costello syndrome with pancreatic islet cell hyperplasia. Am J Med Genet A 130A:402-405. https://doi.org/10.1002/ajmg.a.30288

62. Sheffield BS, Yip S, Ruchelli ED et al (2015) Fatal congenital hypertrophic cardiomyopathy and a pancreatic nodule morphologically identical to focal lesion of congenital hyperinsulinism in an infant with costello syndrome: case report and review of the literature. Pediatr Dev Pathol 18:237-244. https://doi.org/10.2350/1407-1525-CR.1

63. Sun L, Eklund EA, Chung WK et al (2005) Congenital disorder of glycosylation id presenting with hyperinsulinemic hypoglycemia and islet cell hyperplasia. J Clin Endocrinol Metab 90:4371-4375 https://doi.org/jc.2005-0250
64. Drut R, Mortera M, Drut RM (1998) Yolk sac tumor of the placenta in Wiedemann-Beckwith syndrome. Pediatr Dev Pathol 1: 534-537

65. Aoki Y, Niihori T, Kawame $\mathrm{H}$ et al (2005) Germline mutations in HRAS proto-oncogene cause Costello syndrome. Nat Genet 37: 1038-1040. https://doi.org/10.1038/ng1641

66. Hennekam RC (2003) Costello syndrome: an overview. Am J Med Genet C, Semin Med Genet 117C:42-48. https://doi.org/ 10.1002/ajmg.c. 10019

67. Alexander S, Ramadan D, Alkhayyat $\mathrm{H}$ et al (2005) Costello syndrome and hyperinsulinemic hypoglycemia. Am J Med Genet A 139:227-230. https://doi.org/10.1002/ajmg.a.31011

68. Marquardt T, Denecke J (2003) Congenital disorders of glycosylation: review of their molecular bases, clinical presentations and specific therapies. Eur J Pediatr 162:359-379. https://doi.org/10. 1007/s00431-002-1136-0

69. Babovic-Vuksanovic D, Patterson MC, Schwenk WF et al (1999) Severe hypoglycemia as a presenting symptom of carbohydratedeficient glycoprotein syndrome. J Pediatr 135:775-781 https:// doi.org/S0022-3476(99)70103-4

70. Bohles H, Sewell AA, Gebhardt B et al (2001) Hyperinsulinaemic hypoglycaemia-leading symptom in a patient with congenital disorder of glycosylation Ia (phosphomannomutase deficiency). J Inherit Metab Dis 24:858-862

71. Korner C, Knauer R, Stephani U et al (1999) Carbohydrate deficient glycoprotein syndrome type IV: deficiency of dolichyl-P-Man: Man(5)GlcNAc(2)-PP-dolichyl mannosyltransferase. EMBO J 18: 6816-6822. https://doi.org/10.1093/emboj/18.23.6816

72. Clayton PT, Winchester BG, Keir G (1992) Hypertrophic obstructive cardiomyopathy in a neonate with the carbohydrate-deficient glycoprotein syndrome. J Inherit Metab Dis 15:857-861

73. Weber R, Kantor P, Chitayat D et al (2014) Spectrum and outcome of primary cardiomyopathies diagnosed during fetal life. JACCHeart Fail 2:403-411. https://doi.org/10.1016/j.jchf.2014.02.010

74. Pedra SR, Smallhorn JF, Ryan G et al (2002) Fetal cardiomyopathies: pathogenic mechanisms, hemodynamic findings, and clinical outcome. Circulation 106:585-591

75. Hagemann LL, Zielinsky P (1996) Prenatal study of hypertrophic cardiomyopathy and its association with insulin levels in fetuses of diabetic mothers. Arq Bras Cardiol 66:193-198

76. Zielinsky P, da Costa MH, Oliveira LT et al (1997) Natural history of myocardial hypertrophy and its association with hyperinsulinism in infants of diabetic mothers. Arq Bras Cardiol 69:389-394

77. Lusson JR, Gaulme J, Raynaud EJ, Cheynel J (1982) Asymmetrical hypertrophic cardiomyopathy in neonates of diabetic mothers. Arch Fr Pediatr 39:433-436

78. Maron BJ, Roberts WC (1979) Quantitative analysis of cardiac muscle cell disorganization in the ventricular septum of patients with hypertrophic cardiomyopathy. Circulation 59:689-706

79. Sutton MGSJ, Lie JT, Anderson KR et al (1980) Histopathological specificity of hypertrophic obstructive cardiomyopathy. Myocardial fibre disarray and myocardial fibrosis. Br Heart J 44:433-443

80. Shirani J, Pick R, Roberts WC, Maron BJ (2000) Morphology and significance of the left ventricular collagen network in young patients with hypertrophic cardiomyopathy and sudden cardiac death. J Am Coll Cardiol 35:36-44

81. Hovnik T, Bratanic N, Podkrajsek KT et al (2012) Severe progressive obstructive cardiomyopathy and renal tubular dysfunction in Donohue syndrome with decreased insulin receptor autophosphorylation due to a novel INSR mutation. Eur J Pediatr. https:// doi.org/10.1007/s00431-012-1901-7

82. Huang T, Kelly A, Becker SA et al (2013) Hypertrophic cardiomyopathy in neonates with congenital hyperinsulinism. Arch Dis childhoodFetal neonatal Ed 98:F351-F354. https://doi.org/10. 1136/archdischild-2012-302546 
83. Maillet M, van Berlo JH, Molkentin JD (2013) Molecular basis of physiological heart growth: fundamental concepts and new players. Nat Rev cell Biol 14:38-48. https://doi.org/10.1038/nrm3495

84. Zapf J, Schoenle E, Froesch ER (1978) Insulin-like growth factors I and II: some biological actions and receptor binding characteristics of two purified constituents of nonsuppressible insulin-like activity of human serum. Eur J Biochem 87:285-296

85. Bedinger DH, Adams SH (2015) Metabolic, anabolic, and mitogenic insulin responses: a tissue-specific perspective for insulin receptor activators. Mol Cell Endocrinol 415:143-156. https:// doi.org/10.1016/j.mce.2015.08.013

86. Bar RS, Boes M, Dake BL et al (1988) Insulin, insulin-like growth factors, and vascular endothelium. Am J Med 85:59-70

87. Brownsey RW, Boone AN, Allard MF (1997) Actions of insulin on the mammalian heart: metabolism, pathology and biochemical mechanisms. Cardiovasc Res 34:3-24

88. Ren J, Samson WK, Sowers JR (1999) Insulin-like growth factor I as a cardiac hormone: physiological and pathophysiological implications in heart disease. J Mol Cell Cardiol 31:2049-2061

89. Nakae J, Kido Y, Accili D (2001) Distinct and overlapping functions of insulin and IGF-I receptors. Endocr Rev 22:818-835. https://doi.org/10.1210/edrv.22.6.0452

90. Rodriguez M, Alonso L, Alvarez E, Blazquez E (1987) Direct evidence that insulin does not down-regulate its own receptors in circulating monocytes of human newborns. Diabetologia 30:820-822

91. Thorsson AV, Hintz RL (1977) Insulin receptors in the newborn. Increase in receptor affinity and number. N Engl J Med 297:908912. https://doi.org/10.1056/NEJM197710272971704

92. Fazio S, Palmieri EA, Biondi B et al (2000) The role of the GHIGF-I axis in the regulation of myocardial growth: from experimental models to human evidence. Eur J Endocrinol 142:211-216 https://doi.org/1420211

93. Netchine I, Azzi S, Le Bouc Y, Savage MO (2011) IGF1 molecular anomalies demonstrate its critical role in fetal, postnatal growth and brain development. Best Pract Res Endocrinol Metab 25:181-190. https://doi.org/10.1016/j.beem.2010.08.005

94. Laustsen PG, Russell SJ, Cui L et al (2007) Essential role of insulin and insulin-like growth factor 1 receptor signaling in cardiac development and function. Mol Cell Biol 27:1649-1664 https://doi.org/MCB.01110-06

95. Cheitlin MD, Armstrong WF, Aurigemma GP et al (2003) ACC/ AHA/ASE 2003 Guideline Update for the Clinical Application of Echocardiography: summary article. A report of the American College of Cardiology/American Heart Association Task Force on Practice Guidelines ACC/AHA/ASE Committee to Update the 1997 Guid. J Am Soc Echocardiogr 16:1091-1110. https:// doi.org/10.1016/S0894-7317(03)00685-0

96. Aynsley-Green A, Hussain K, Hall J et al (2000) Practical management of hyperinsulinism in infancy. Arch Dis childhoodFetal neonatal Ed 82:F98-F107

97. Palladino AA, Stanley CA (2010) The hyperinsulinism/ hyperammonemia syndrome. Rev Endocr Metab Disord 11: 171-178. https://doi.org/10.1007/s11154-010-9146-0

98. Wertheimer E, Lu SP, Backeljauw PF et al (1993) Homozygous deletion of the human insulin receptor gene results in leprechaunism. Nat Genet 5:71-73. https://doi.org/10.1038/ ng0993-71

99. Flier JS, Usher P, Moses AC (1986) Monoclonal antibody to the type I insulin-like growth factor (IGF-I) receptor blocks IGF-I receptor-mediated DNA synthesis: clarification of the mitogenic mechanisms of IGF-I and insulin in human skin fibroblasts. Proc Natl Acad Sci U S A 83:664-668
100. Geffner ME, Kaplan SA, Bersch N et al (1987) Leprechaunism: in vitro insulin action despite genetic insulin resistance. Pediatr Res 22:286-291

101. Hone J, Accili D, Psiachou H et al (1995) Homozygosity for a null allele of the insulin receptor gene in a patient with leprechaunism. Hum Mutat 6:17-22. https://doi.org/10.1002/humu.1380060105

102. Spudich JA (2014) Hypertrophic and dilated cardiomyopathy: four decades of basic research on muscle lead to potential therapeutic approaches to these devastating genetic diseases. Biophys J 106:1236-1249. https://doi.org/10.1016/j.bpj.2014.02.011

103. Jr WWH, Raju TN, Higgins RD et al (2009) Knowledge gaps and research needs for understanding and treating neonatal hypoglycemia: workshop report from Eunice Kennedy Shriver National Institute of Child Health and Human Development. J Pediatr 155: 612-617. https://doi.org/10.1016/j.jpeds.2009.06.044

104. Abu-Osba YK, Manasra KB, Mathew PM (1989) Complications of diazoxide treatment in persistent neonatal hyperinsulinism. Arch Dis Child 64:1496-1500

105. Timlin MR, Black AB, Delaney HM et al (2017) Development of pulmonary hypertension during treatment with diazoxide: a case series and literature review. Pediatr Cardiol 38:1247-1250. https:// doi.org/10.1007/s00246-017-1652-3

106. Senniappan S, Alexandrescu S, Tatevian N et al (2014) Sirolimus therapy in infants with severe hyperinsulinemic hypoglycemia. $\mathrm{N}$ Eng1 J Med 370:1131-1137. https://doi.org/10.1056/ NEJMoa1310967

107. Madiraju AK, Erion DM, Rahimi Y et al (2014) Metformin suppresses gluconeogenesis by inhibiting mitochondrial glycerophosphate dehydrogenase. Nature 510:542-546. https://doi.org/10. 1038/nature 13270

108. Backeljauw PF, Alves C, Eidson M, et al (1994) Effect of intravenous insulin-like growth factor I in two patients with leprechaunism. Pediatr Res 36:749-754. https://doi.org/10.1203/ 00006450-199412000-00012

109. Planchenault D, Martin-Coignard D, Rugemintwaza D et al (2014) Donohue syndrome or leprechaunism. Arch Pediatr 21: 206-210. https://doi.org/10.1016/j.arcped.2013.11.016

110. Hovnik T, Bratanic N, Podkrajsek KT et al (2013) Severe progressive obstructive cardiomyopathy and renal tubular dysfunction in Donohue syndrome with decreased insulin receptor autophosphorylation due to a novel INSR mutation. Eur J Pediatr 172:11251129. https://doi.org/10.1007/s00431-012-1901-7

111. Satoh M, Yoshizawa A, Takesue M et al (2006) Long-term effects of recombinant human insulin-like growth factor I treatment on glucose and lipid metabolism and the growth of a patient with congenital generalized lipodystrophy. Endocr J 53:639-645

112. Chan JL, Lutz K, Cochran E et al (2011) Clinical effects of longterm metreleptin treatment in patients with lipodystrophy. Endocr Pract 17:922-932. https://doi.org/10.4158/EP11229.OR

113. Alvares RF, Goodwin JF (1982) Non-invasive assessment of diastolic function in hypertrophic cardiomyopathy on and off beta adrenergic blocking drugs. Br Heart J 48:204-212

114. Bourmayan C, Razavi A, Fournier C et al (1985) Effect of propranolol on left ventricular relaxation in hypertrophic cardiomyopathy: an echographic study. Am Heart J 109:1311-1316

115. de Graaf M, Breur JM, Raphael MF et al (2011) Adverse effects of propranolol when used in the treatment of hemangiomas: a case series of 28 infants. J Am Acad Dermatol 65:320-327. https://doi. org/10.1016/j.jaad.2010.06.048

Publisher's note Springer Nature remains neutral with regard to jurisdictional claims in published maps and institutional affiliations. 